\title{
BŪSIMUUJŲ SVEIKATOS PRIEŽIŪROS SPECIALISTŲ POŽIŪRIS İ ŽMOGAUS PAPILOMOS VIRUSĄ IR VAKCINĄ NUO ŠIO VIRUSO
}

\author{
Dovilė Banaitytė ${ }^{1}$, Erika Jauraitè ${ }^{1}$, Snieguolė Kaselienè ${ }^{2}$ \\ ${ }^{1}$ Lietuvos sveikatos mokslu universiteto Medicinos fakultetas \\ ${ }^{2}$ Lietuvos sveikatos mokslu universiteto Visuomenès sveikatos fakultetas, Sveikatos vadybos katedra
}

Raktažodžiai: žmogaus papilomos virusas, informuotumas, požiūris ị vakciną, studentai.

\section{Santrauka}

Lietuvoje kasmet užregistruojama apie 450 naujų gimdos kaklelio véžio atvejų. Moksliniais tyrimais įrodyta, jog žmogaus papilomos virusas (ŽPV) yra svarbus veiksnys gimdos kaklelio vėžio patogenezèje, todèl susirgimų skaičių galima sumažinti pasitelkus vakciną nuo šio viruso. Medicinos darbuotojai užima svarbią vietą gyventojų švietime ir gali prisidèti prie vakcinacijos apimčių didinimo, tačiau vis dar trūksta išsamiu tyrimų, kurie vertintų būsimujų sveikatos priežiūros specialistų žinias apie ŽPV ir požiūrị ị vakciną nuo ŽPV.

Tyrimo tikslas - išsiaiškinti Lietuvos sveikatos mokslų universiteto (LSMU) Medicinos ir Slaugos fakultetų studentų informuotumą bei požiūrị ị ŽPV ir vakciną nuo šio viruso.

Tyrimo medžiaga ir metodai. Anoniminès anketinès apklausos būdu apklausti 278 LSMU Medicinos fakulteto studentai ir 58 Slaugos fakulteto studentai. Apklausa buvo vykdoma nuo $2020 \mathrm{~m}$. vasario iki $2021 \mathrm{~m}$. vasario mènesio. Statistinè duomenų analizè atlikta naudojant IBM SPSS 26.0 versiją. Sąsajoms nustatyti taikytas chi kvadrato $\left(\chi^{2}\right)$ kriterijus bei porinis palyginimas $z$ testu. Tyrimo rezultatai laikyti statistiškai reikšmingais, kai $\mathrm{p}<0,05$.

Rezultatai. LSMU Medicinos ir Slaugos fakultetų studentai teisingai nurodè šiuos galimus ŽPV plitimo būdus: 94,3 proc. - lytinių santykių metu, 21,8 proc. - vertikalusis būdas, 35,7 proc. - kontaktinis būdas. Net 93,2 proc. žinojo, kad ŽPV gali sukelti gimdos kaklelio vėži, tačiau varpos vė̌̌i ir paprastąsias karpas teisingai pasirinko atitinkamai tik 35,1 proc. bei 23,3 proc. respondentų. Apie tai, jog yra sukurta vakcina nuo ŽPV, žino 86,6 proc. studentų. Daugiau nei pusè (54,2 proc.) apklaustujų teisingai nurodé, jog vakcina nuo ŽPV gali skiepytis tiek moterys, tiek vyrai, o 58,2 proc. žinojo, jog patariama skiepytis iki pirmujų lytinių santykių. Daugiau nei 70 proc. tiriamųjų nurodè, jog jiems trūksta informacijos apie ŽPV ir vakciną nuo ŽPV, todèl noretų sužinoti daugiau. Tik 11,6 proc. apklaustujų yra pasiskiepiję vakcina nuo ŽPV, o ateityje skiepytis planuoja 22,7 proc. iki šiol nepasiskiepijusių vyrų ir 39,4 proc. moterų. 78 proc. studentų skiepytų savo vaikus vakcina nuo ŽPV, tai labiau linkę daryti vyriškos lyties bei vyresniųjų kursų (IV-VI) studentai $(\mathrm{p}<0,05)$. Vyresniujų kursų (IV-VI) studentai buvo geriau informuoti apie ŽPV ir vakciną nuo ŽPV, jų požiūris i vakciną buvo palankesnis.

Išvados. Nors LSMU Medicinos ir Slaugos fakultetų studentai turi pagrindinę informaciją apie ŽPV ir vakciną nuo ŽPV, tačiau žinių kiekis yra nepakankamas. Didžioji dalis apklaustųjų nurodè, jog norètų gauti daugiau informacijos.

\section{Ivadas}

Žmogaus papilomos virusas - vienas dažniausių patogenų, perduodamas lytinių santykių metu, vertikaliu ar artimo odos ir gleivinių sąlyčio būdu [1]. Infekcijos šaltinis yra sergantis žmogus ar viruso nešiotojas, užsikrèsti gali tiek vyrai, tiek moterys. Nors daugumai užsikrètusiujų ŽPV infekcija praeina savaime ir nesukelia jokių simptomų, tačiau ji gali persistuoti žmogaus organizme, sukelti ikivėžines būkles, věžinius susirgimus bei kitas odos ir gleivinių patologijas, tokias kaip odos karpos, gerybinès nosies ir burnos ertmès, gerklès ir gerklų bei lytinių takų papilomos [2-4]. Nors dažniausiai minimas ŽPV vaidmuo gimdos kaklelio vėžio patogenezèje, tačiau jis sukelia apie 95 proc. išangès, 70 proc. orofaringinių, 60 proc. makšties, 50 proc. išorinių lyties organų bei 35 proc. varpos navikinių susirgimų [2,5-7].

Europoje patvirtintos 3 ŽPV vakcinos: dvivalente Cervarix $^{\circledR}$ vakcina nuo 16 ir 18 ŽPV tipu, keturvalente Gardasil ${ }^{\circledR}$ $\left(\right.$ atitikmuo - Silgard $^{\circledR}$ ) vakcina nuo 6, 11, 16, 18 ŽPV tipų bei devynvalentė Gardasil $9^{\circledR}$ vakcina [8]. Nustatyta, kad pasitelkus vakcinas nuo ŽPV, apsaugančias nuo 16 ir 18 ŽPV tipų, galima išvengti apie 70 proc. visų gimdos kaklelio vėžio atvejų. I Lietuvos Respublikos profilaktinių skiepijimų kalendorių nuo 2016 m. ịtraukta dvivalentė Cervarix ${ }^{\circledR}$ vak- 
1 lentelè. Respondentų atsakymų ị klausimą „Ką, jūsų manymu, sukelia ŽPV?“ pasiskirstymas pagal lytị ir kursą.

\begin{tabular}{|c|c|c|c|c|c|c|c|c|c|c|}
\hline \multirow{3}{*}{ Atsakymai } & \multicolumn{5}{|c|}{ Lytis } & \multicolumn{5}{|c|}{ Kursas } \\
\hline & \multicolumn{2}{|c|}{$\begin{array}{l}\text { moterys } \\
(\mathrm{n}=292)\end{array}$} & \multicolumn{2}{|c|}{$\begin{array}{c}\text { vyrai } \\
(n=44)\end{array}$} & \multirow{2}{*}{ Statistika } & \multicolumn{2}{|c|}{ I-III $(n=166)$} & \multicolumn{2}{|c|}{$\begin{array}{l}\text { IV-VI } \\
(n=170)\end{array}$} & \multirow{2}{*}{ Statistika } \\
\hline & $\mathrm{n}$ & proc. & $\mathrm{n}$ & proc. & & $\mathrm{n}$ & proc. & $\mathrm{n}$ & proc. & \\
\hline $\begin{array}{l}\text { Gimdos kakle- } \\
\text { lio vèži }\end{array}$ & 274 & 93,8 & 39 & 88,6 & $\begin{array}{c}\chi^{2}=1,621 ; 11 s=1 \\
p=0,203\end{array}$ & 144 & 86,7 & 169 & 99,4 & $\begin{array}{c}\chi^{2}=21,126 ; 11 s=1 ; \\
p=0,001\end{array}$ \\
\hline Varpos vėžị & 105 & 35,9 & 13 & 29,5 & $\begin{array}{c}\chi^{2}=0,690 ; 11 s=1 ; \\
p=0,406\end{array}$ & 46 & 27,7 & 72 & 42,3 & $\begin{array}{c}\chi^{2}=7,9 ; 11 s=1 ; \\
p=0,005\end{array}$ \\
\hline $\begin{array}{l}\text { Paprastąsias } \\
\text { karpas }\end{array}$ & 140 & 47,9 & 20 & 45,5 & $\begin{array}{c}\chi^{2}=0,095 ; 11 s=1 \\
p=0,758\end{array}$ & 69 & 41,5 & 91 & 53,5 & $\begin{array}{c}\chi^{2}=4,819 ; 11 s=1 ; \\
p=0,028\end{array}$ \\
\hline $\begin{array}{l}\text { Šlapimo takų } \\
\text { infekciją }\end{array}$ & 23 & 7,8 & 6 & 2,0 & $\begin{array}{c}\chi^{2}=1,609 ; 11 s=1 \\
p=0,205\end{array}$ & 17 & 10,2 & 12 & 7,0 & $\begin{array}{c}\chi^{2}=1,078 ; 11 s=1 ; \\
p=0,299\end{array}$ \\
\hline $\begin{array}{l}\text { Storosios žar- } \\
\text { nos vėžị }\end{array}$ & 36 & 12,3 & 7 & 2,4 & $\begin{array}{c}\chi^{2}=0,439 ; 11 s=1 \\
p=0,507\end{array}$ & 18 & 10,8 & 25 & 14,7 & $\begin{array}{c}\chi^{2}=1,123 ; 11 s=1 \\
p=0,289\end{array}$ \\
\hline Meningitą & 6 & 2,0 & 2 & 0,6 & $\begin{array}{c}\chi^{2}=1,021 ; 11 s=1 \\
p=0,312\end{array}$ & 5 & 3,0 & 3 & 1,7 & $\begin{array}{c}\chi^{2}=0,562 ; 11 \mathrm{~s}=1 \\
\mathrm{p}=0,453\end{array}$ \\
\hline Nežinau & 13 & 4,5 & 3 & 1,0 & $\begin{array}{c}\chi^{2}=0,472 ; 11 s=1 \\
p=0,492\end{array}$ & 16 & 9,6 & 0 & 0,0 & $\begin{array}{c}\chi^{2}=17,205 ; 11 s=1 ; \\
p=0,001\end{array}$ \\
\hline
\end{tabular}

cina, kuria pradètos skiepyti $11 \mathrm{~m}$. mergaitės [9]. Nepaisant galimybès pasiskiepyti nuo ŽPV infekcijos, ŽPV sukelti navikiniai susirgimai ir toliau yra pirmaujanti mirties priežastis daugelyje šalių. Europoje kiekvienais metais nustatoma apie 33 tūkst., o Lietuvoje - 450 naujų gimdos kaklelio vėžio atvejų. Kas antra moteris, kuriai diagnozuotas gimdos kaklelio vėžys, miršta [10].

Tyrimai rodo, kad šalyse, kuriose daugiau nei 50 proc. moterų buvo pasiskiepijusios, 16 ir 18 tipo ŽPV užsikrètusių asmenų skaičius sumažèjo 61 procentu. Užkrečiamųjų ligu ir AIDS centro duomenimis, Lietuvoje skiepijimų apimtys 2017-2019 m. nuo ŽPV tiek pirmaja, tiek antraja vakcinos doze ženkliai padidèjo - atitinkamai pirmaja doze nuo 43,2 iki 77,2 proc. bei antraja doze nuo 27,2 iki 65,7 procento [11].

Tyrimo tikslas - išsiaiškinti LSMU Medicinos ir Slaugos fakultetų studentų informuotumą bei požiūrị i Ž ŽPV ir vakciną nuo šio viruso.

\section{Tyrimo medžiaga ir metodai}

Darbo tikslui pasiekti sukurtas originalus klausimynas. Jị sudarè 3 dalys: 1 dalis- studento socialinè ir demografinè padètis; 2 dalis - informuotumas apie ŽPV bei vakciną nuo ŽPV; 3 dalis - požiūris ị vakciną nuo ŽPV. Anketoje buvo klausiama respondento amžiaus, lyties, kurso, fakulteto, kuriame studijuojama. Respondento informuotumas apie ŽPV buvo vertinamas klausiant apie viruso plitimo kelius, sukeliamas ligas, respondentui vertinant teisingus (neteisingus) teiginius apie ŽPV. Nuomonè ir informuotumas apie vakciną nuo ŽPV vertinti klausiant, ar respondentas girdèjęs apie vakciną, iš kur sužinojo apie ją, kokius šalutinius reiškinius gali sukelti vakcina, ar respondentas pasiskiepijęs ir kokia pasiskiepijimo (nesiskiepijimo) priežastis, ar skiepytų savo vaikus. Anoniminès anketinès apklausos būdu apklausti 278 LSMU Medicinos fakulteto studentai ir 58 Slaugos fakulteto studentai ( 86,9 proc. moterų ir 13,1 proc. - vyrų). Apklausa buvo vykdoma nuo $2020 \mathrm{~m}$. vasario iki $2021 \mathrm{~m}$. vasario. Vidutinis tiriamujų amžius - 22 (standartinis nuokrypis 2,5) metai. Statistinė duomenų analizė atlikta naudojant IBM SPSS 26.0 versiją. Skirtumui tarp grupių nustatyti taikytas chi kvadrato $\left(\chi^{2}\right)$ kriterijus bei porinis palyginimas $\mathrm{z}$ testu. Statistinio reikšmingumo lygmuo $\alpha=0,05$. Tyrimo rezultatai laikyti statistiškai reikšmingais, kai p<0,05.

\section{Tyrimo rezultatai}

Informuotumas apie ŽPV. Dauguma respondentų $(94,3$ proc.) žinojo, kad ŽPV plinta lytinių santykių metu, 21,8 proc. nurodè vertikaluji būdą, o trečdalis (35,7 proc.) apklaustujų teisingai nurode, jog virusas plinta kontaktiniu būdu. 64,9 proc. studentų žinojo, jog užsikrètus ŽPV pirmieji simptomai gali pasireikšti tik po kurio laiko.

Net 93,2 proc. apklaustujų žinojo, kad ŽPV gali sukelti gimdos kaklelio vėži, 23,3 proc. teisingai nurodè, jog ŽPV taip pat gali sukelti paprastąsias karpas, apie šio viruso vaidmenį varpos vėžio patogenezeje žinojo 35,1 proc. respondentų. Respondentų atsakymų ị klausimą „Ką, jūsų 


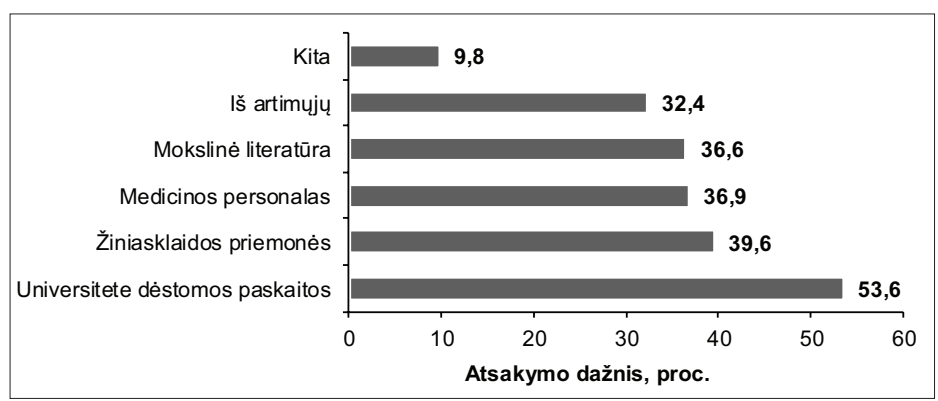

1 pav. Pagrindiniai informacijos apie ŽPV ir vakciną šaltiniai

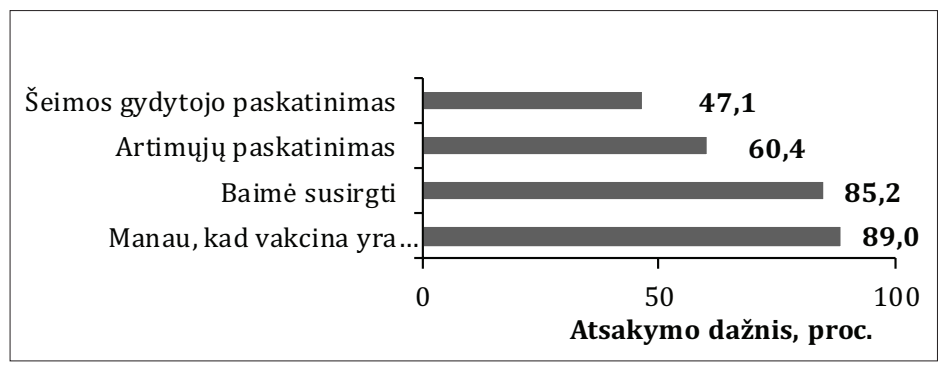

2 pav. Respondentų nurodytos pasiskiepijimo nuo ŽPV priežastys

2 lentelè. Atsakymų i klausimą „Ar esate pasiskiepiję nuo ŽPV?“ pasiskirstymas pagal respondentų lytị.

$\chi^{2}=9,8181 ;$ lls $=3 ; p<0,05 ;$ statistiškai reikšmingas skirtumas lyginant su vyrais $(p<0,05)$

\begin{tabular}{|l|l|l|l|l|l|l|l|}
\hline \multirow{2}{*}{ Atsakymai ị klausimą } & \multicolumn{4}{l}{ Lytis } \\
\cline { 2 - 9 } & \multicolumn{2}{|l|}{ moterys $(\mathrm{n}=292)$} & \multicolumn{2}{l|}{ vyrai $(\mathrm{n}=44)$} & \multicolumn{2}{l|}{ 1š viso (n=336) } \\
\cline { 2 - 9 } & $\mathrm{n}$ & proc. & $\mathrm{n}$ & proc. & $\mathrm{n}$ & proc. \\
\hline Taip & 37 & 12,7 & 2 & 4,6 & 39 & 11,6 \\
\hline Ne, ateityje pasiskiepyti neplanuoju & 114 & $39,0^{*}$ & 27 & 61,4 & 141 & 41,9 \\
\hline $\begin{array}{l}\text { Ne, tačiau planuoju pasiskiepyti } \\
\text { ateityje }\end{array}$ & 115 & $39,4^{*}$ & 10 & 22,7 & 125 & 37,3 \\
\hline Nežinau & 26 & 8,9 & 5 & 11,3 & 31 & 9,2 \\
\hline
\end{tabular}

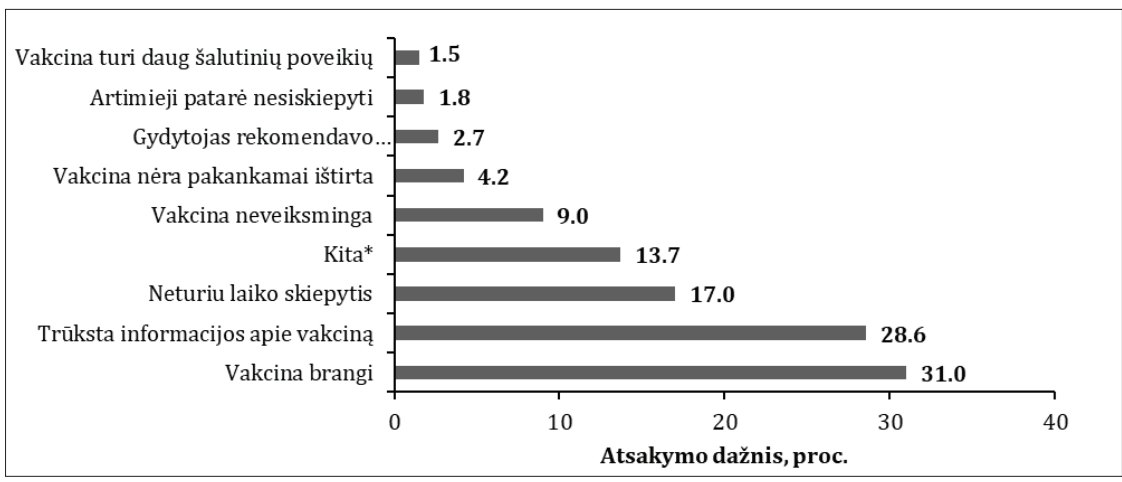

3 pav. Nesiskiepijimo nuo ŽVP priežastys

*nepasiskiepijo iki lytiniu santykiu pradžios, nèra lytiniu partneriu kaitos, vyriška lytis manymu, sukelia ŽPV“" pasiskirstymas pagal lytị ir kursą pateiktas 1 lentelèje. Statistiškai reikšmingo ryšio tarp lyties ir pasirinkto atsakymo nenustatyta ( $>00,05)$. Nustatyta, jog vyresniujų kursų (IV-VI) studentai buvo labiau linkę rinktis teisingus atsakymus: apie gimdos kaklelio vèžį (86,7 proc. I-III kurso ir 99,4 proc. IV-VI kurso; $\mathrm{p}<0,05)$, varpos véži (atitinkamai 27,7 proc. ir 42,3 proc.; $\mathrm{p}<0,05$ ). Atsakymą ,nežinau“ dažniau rinkosi I-III kurso studentai nei IV-VI (atitinkamai 9,6 proc. ir 0 proc.; $\mathrm{p}<0,05) .74,4$ proc. apklaustujų teigè, kad informacijos apie ŽPV jiems trūksta, todèl norètų sužinoti daugiau (1 lentelè).

Informuotumas apie vakciną nuo ŽPV. Apie tai, jog yra sukurta vakcina nuo ŽPV, žinojo 86,6 proc. apklaustujų. Nenustatytas ryšys tarp informuotumo ir lyties $(\mathrm{p}<0,05)$, tačiau žinios priklausė nuo kurso $\left(\chi^{2}=29,010 ; 11 s=2 ; p<0,05\right)-$ vyresniujų kursų studentai buvo geriau informuoti ir dažniau rinkosi teigiamą atsakymą (76,5 proc. I-III kurso studentų ir 96,4 proc. IV-VI kurso studentų; $p<0,05)$.

54,2 proc. tiriamujų teisingai nurode, jog vakcina nuo ŽPV gali skiepytis tiek moterys, tiek vyrai, 58,2 proc. žinojo, jog patariama skiepytis iki pirmujų lytinių santykių, o 74,8 proc. teisingai nurode, jog moterys, net ir pasiskiepijusios vakcina nuo ŽPV, turi dalyvauti gimdos kaklelio véžio prevencijos programoje.

Dauguma respondentų žinojo apie pagrindinius galimus šalutinius vakcinos poveikius: skausmą ir patinimą dūrio vietoje ( 71,1 proc.), nežymų karščiavimą (57,7 proc.), tačiau 25 proc. apklaustųjų negalèjo ịvardinti nei vieno galimo šios vakcinos šalutinio poveikio. Jaunesniųjų kursų (I-III) studentai šalutinių poveikių nežinojo dažniau (atsakymą ,nežinau" pasirinko 37,3 proc. I-III kurso ir 12,9 proc. IV-VI kurso studentų; $\mathrm{p}<0,05)$. Statistiškai reikšmingo skirtumo tarp lyčių nenustatyta $(\mathrm{p}>0,05)$.

Pagrindiniai tiriamujų nurodyti informacijos apie ŽPV ir vakciną nuo ŽPV šaltiniai pateikti 1 paveiksle. Dažniausiai nurodytas informacijos šaltinis - universitete dėstomos pas- 
kaitos (53,6 proc.), informacijos paieška žiniasklaidoje (39,6 proc.), mokslinèje literatūroje ( 36,6 proc.). 36,9 proc. respondentų minètą informaciją gavo iš medicinos personalo. 69,4 proc. tiriamujų nurodè, jog turi nepakankamai žinių apie vakciną nuo ŽPV, todèl norètų gauti daugiau informacijos.

Požiūris ị vakciną nuo ŽPV. Tik 11,6 proc. apklaustųjų (12,7 proc. moterų ir 4,5 proc. vyrų) buvo pasiskiepiję ŽPV vakcina. Ateityje skiepytis planuoja 22,7 proc. iki šiol nepasiskiepijusių vyrų ir 39,4 proc. moterų, skiepytis atsisako 39,0 proc. moterų bei 61,4 proc. vyrų ( 2 lentelè). Statistiškai reikšmingo skirtumo tarp lyčių ar kursų nenustatyta $(\mathrm{p}>0,05)$.

Tiriamujų nurodytos priežastys, paskatinusios pasiskiepyti nuo ŽPV, pateikiamos 2 paveiksle. Dauguma tiriamujų teigè, jog apsispręsti skiepytis padejjo manymas, kad vakcina yra veiksminga bei baimè susirgti ŽPV, tačiau tik 47,1 proc. respondentų tai padaryti patarè šeimos gydytojas.

Apklaustujų nurodytos nesiskiepijimo priežastys pateikiamos 3 paveiksle. Dažniausios iš jų: vakcinos kaina (31,0 proc.), informacijos apie vakciną trūkumas ( 28,6 proc.), laiko trūkumas (17,0 proc.), manymas, jog vakcina nèra veiksminga ( 9 proc.). Statistiškai reikšmingo ryšio tarp nesiskiepijimo priežasčių ir lyties ar kurso nenustatyta $(\mathrm{p}>0,05)$.

Vakcina nuo ŽPV 78 proc. apklaustujų skiepytų savo vaikus, 17,9 proc. neapsisprendę, o 4,1 proc. atsisakytų skiepyti savo vaikus. Šis pasirinkimas priklausè nuo amžiaus ir lyties: vyriškos lyties $(78,4 \%$ vyrų ir $75 \%$ moterų; $p<0,05)$ bei vyresniujų kursų studentai (71\% I-III kurso ir $84,7 \%$ IV-VI kurso; $\mathrm{p}<0,05$ ) labiau linkę ateityje skiepyti savo vaikus.

\section{Rezultatų aptarimas}

Dažniausiai minimas ŽPV vaidmuo gimdos kaklelio véžio išsivystymui, todèl daugelis ( 93,2 proc.) apklausos dalyvių žinojo, kad ŽPV gali sukelti šị susirgimą. Apie kitas patologijas, kurias gali sukelti šis virusas, kalbama rečiau, tad tik 35,1 proc. tyrimo dalyvių nurode, jog ŽPV gali sukelti varpos vėžį, 23,3 proc. - paprastąsias karpas. Šis informacijos trūkumas stebimas ir kitose šalyse. Panašiame tyrime, atliktame 2020 metais Kinijoje, 94,0 proc. tyrimo dalyviu žinojo, kad ŽPV gali sukelti gimdos kaklelio vèžị, 32,7 proc. - varpos vėžį, 66,1 proc. - paprastąsias karpas [12].

Didžioji dalis apklaustujų nurode, jog turi nepakankamai žinių ir norètų sužinoti daugiau apie ŽPV ir vakciną nuo šio viruso (atitinkamai 69,4 proc. ir 74,4 proc.). Lyginant mūsų gautus rezultatus su Kinijoje Huachun Zou ir kt. (2016) atlikto tyrimo duomenimis, LSMU Medicinos ir Slaugos fakultetų studentai turi daugiau žinių apie vakciną nuo ŽPV. 86,6 proc. mūsų apklausoje dalyvavusių studentų žinojo, jog yra sukurta ŽPV vakcina. Šią informaciją žinojo tik 10,3 proc. studentų, dalyvavusių Kinijoje atliktoje apklausoje [13]. Lyginant LSMU būsimų sveikatos priežiūros speci- alistų informuotumą su kitomis populiacijomis, išryškėjo idomios tendencijos. Lenkijoje 2021 metais atlikto tyrimo metu buvo vertinama gydytojų rezidentų nuomonè ir žinios apie ŽPV ir jo prevenciją. Paaiškejjo, kad žinios apie vakciną buvo vertinamos kaip labai prastos, jos nepriklausė nuo lyties, amžiaus ar specializacijos [14]. Vis dèlto 2020 metais atlikus sisteminę literatūros apžvalgą, kurioje buvo analizuojamos Europoje gyvenančių jaunų žmonių ir jų tėvų žinios ir požiūris į ŽPV, prieita prie išvados, kad žinios apie ŽPV ir požiūris ị vakciną yra nepakankamos arba vidutinio lygio ir labai priklausè nuo šalies, kurioje gyvenama [15]. Galima daryti prielaidą, kad žinios priklausè nuo šalies politikos ir gyvenimo lygio: ar vakcinos įtraukiamos ị skiepų kalendorių, prevencinių programų viešinimas žiniasklaidoje, informacijos prieinamumas, gyventojų išsilavinimo lygis.

Vertinant studentų informuotumą, išryškejjo skirtumas tarp kursų: kaip ir tikètasi, vyresniųų kursų (IV-VI) studentai buvo geriau informuoti, jų požiūris ị vakciną buvo palankesnis. Dažnai požiūriui įtakos turi ir šaltiniai, iš kurių asmuo gauna informaciją tam tikra tema. Mūsų atlikto tyrimo dalyviai nurode šiuos informacijos šaltinius: universitete dèstomos paskaitos (53,6 proc.), žiniasklaida (39,6 proc.), medicinos personalas ( 36,9 proc.), mokslinè literatūra $(36,6$ proc.). Tyrimo, atlikto Italijoje (2020), dalyviai nurodè šiuos informacijos šaltinius: šeimos nariai ( 43,7 proc.), internetiniai puslapiai ( 23,9 proc.), déstytojai ( 25,1 proc.), sveikatos specialistai $(23,6$ proc.) [16]. Mūsų tyrime dalyvavę LSMU studentai labiau linkę rinktis ne žiniasklaidos priemones, kuriose galima ir klaidinanti informacija, o tyrimais paremta literatūrą ar specialistų rekomendacijas.

Vis dèlto, tik 11,6 proc. visų tiriamujų yra pasiskiepiję vakcina nuo ŽPV. Tyrimo JAV (2019) metu nustatyta, jog 44 proc. tyrime dalyvavusių medicinos studentų yra pasiskiepiję vakcina nuo ŽPV. Daugiau nei ketvirtadalis (26,7 proc.) apklaustų Italijoje (2019) gyvenančiu studentų nurodè, jog yra pasiskiepiję šia vakcina [17]. Tai rodo, jog mūsų apklaustųų pasiskiepijimo dažnis yra ženkliai mažesnis, tačiau 22,7 proc. iki šiol nepasiskiepijusių vaikinų ir 39,4 proc. merginu yra linkę skiepytis vakcina nuo ŽPV ateityje. Lyginant su tyrimo, atlikto 2016 metais Kinijoje, rezultatais, Kinijos studentai yra labiau linkę skiepytis ateityje (71,8 proc. vyrų ir 69,4 proc. moterų) [18].

Nuo 2016 m. ị Lietuvos Respublikos profilaktinių skiepijimų kalendorių buvo įtraukta dvivalentė Cervarix ${ }^{\circledR}$ vakcina, ja pradètos skiepyti $11 \mathrm{~m}$. mergaitès. Vyresniems asmenims, norintiems pasiskiepyti nuo ŽPV, vakcina yra per brangi ir nefinansuojama valstybės lëšomis, o tai yra viena pagrindinių atsisakymo skiepytis priežasčių. Tai patvirtino ir mūsų atliktas tyrimas. Paklausus, kokia yra nesiskiepijimo priežastis, dažniausi atsakymai buvo vakcinos kaina $(31,0$ proc.) bei 
informacijos apie vakciną trūkumas (28,6 proc.), todèl, siekiant padidinti vakcinacijos apimtis, reiketų gerinti vakcinos prieinamumą, svarstyti galimybę suteikti finansinių lengvatų kitų amžiaus grupių asmenims, norintiems pasiskiepyti šia vakcina, bei teikti suprantamą ir pagrịstą informaciją apie prevencijos galimybes.

LSMU studijuojantys būsimieji sveikatos priežiūros specialistai yra informuoti apie ŽPV ir prevenciją nuo jo, tačiau žinių vis dar trūksta. Labai svarbu gerinti pagrịstos informacijos prieinamumą, skatinti esamus ir būsimus sveikatos priežiūros specialistus domètis ŽPV, jo vaidmeniu ligų išsivystymui bei prevencija, norint užtikrinti didejjančias vakcinacijos apimtis ir sumažinti sergamumą gimdos kaklelio věžiu Lietuvoje.

\section{Išvados}

1. Ne visi LSMU Medicinos ir Slaugos fakultetų studentai turi pakankamai žinių apie ŽPV. Respondentai teisingai nurodè pagrindinị viruso plitimo būdą, tačiau tik nedaugelis žinojo ir kitus galimus šio viruso perdavimo būdus. Didžioji dalis studentų nurode, jog ŽPV gali sukelti gimdos kaklelio vèži, tačiau apie šio viruso ịtaką kitų ligų patogenezei žinojo nedaugelis. Net 74,4 proc. apklaustujjų nurodè, kad informacijos apie ŽPV jiems trūksta ir norètų sužinoti daugiau.

2. Daugiau nei pusė apklaustujų žinojo pagrindinę informaciją apie vakciną nuo ŽPV, tačiau informacijos kiekis nèra pakankamas, todèl net beveik 70 proc. studentų nurodè, jog noretų gauti daugiau informacijos šia tema.

3. Tik apie ketvirtadali iki šiol nepasiskiepijusių vyrų ir beveik puse moterų yra linkę skiepytis ŽPV vakcina ateityje. Net 78 proc. apklausos dalyvių nurodé, jog skiepytų savo vaikus ŽPV vakcina, labiau linkę tai daryti moteriškosios lyties bei jaunesniujų kursų studentai $(\mathrm{p}<0,05)$.

\section{Literatūra}

1. Harden ME, Munger K. Human papillomavirus molecular biology. Mutation Research 2017;772:3.

https://doi.org/10.1016/j.mrrev.2016.07.002

2. Serrano B, Brotons M, Bosch FX, Bruni L. Epidemiology and burden of HPV-related disease. Best Practice \& Research Clinical Obstetrics \& Gynaecology 2018;47:14-26.

https://doi.org/10.1016/j.bpobgyn.2017.08.006

3. Luria L, Cardoza-Favarato G, Doerr C. Human Papillomavirus (Nursing). StatPearls 2021.

4. Lei J, Ploner A, Elfström KM, Wang J, Roth A, Fang F, et al. HPV Vaccination and the Risk of Invasive Cervical Cancer. Https://DoiOrg/101056/NEJMoa1917338 2020;383:1340-8. https://doi.org/10.1056/NEJMoa1917338

5. Viens LJ, Henley SJ, Watson M, Markowitz LE, et al. Human Papillomavirus-Associated Cancers - United States, 2008-
2012. MMWR Morbidity and Mortality Weekly Report 2016;65:661-6.

https://doi.org/10.15585/mmwr.mm6526a1

6. Harden ME, Munger K. Human papillomavirus molecular biology. Mutation Research Reviews in Mutation Research 2017;772:3-12.

https://doi.org/10.1016/j.mrrev.2016.07.002

7. Chaturvedi AK, Engels EA, Pfeiffer RM, Hernandez BY, Xiao W, Kim E, et al. Human Papillomavirus and Rising Oropharyngeal Cancer Incidence in the United States. Journal of Clinical Oncology 2011;29:4294.

https://doi.org/10.1200/JCO.2011.36.4596

8. Castle PE, Maza M. Prophylactic HPV vaccination: past, present, and future. Epidemiology Infection 2016;144:449-68. https://doi.org/10.1017/S0950268815002198

9. Lietuvos Respublikos sveikatos apsaugos ministro $2014 \mathrm{~m}$. sausio 3 d. ịsakymas Nr. V-8 Dèl nacionalinès imunoprofilaktikos 2014-2018 metų programos patvirtinimo. https://e-seimas.lrs. 1t/portal/legalAct/lt/TAD/d3e175107a7411e38df3da592f4236 cc?jfwid=11dyheh70k

10. Serrano B, Brotons M, Bosch FX, Bruni L. Epidemiology and burden of HPV-related disease. Best Practice Research Clinical Obstetrics Gynaecology 2018;47:14-26. https://doi.org/10.1016/j.bpobgyn.2017.08.006

11. ULAC. Skiepijimai nuo ŽPV per porą metų reikšmingai padidèjo. 2020. http://www.ulac.lt/naujienos/pranesimai-spaudai/ skiepijimai-nuo-zpv-per-pora-metu-reiksmingai-padidejo

12. Wang S, Han B, Wan Y, Liu J, Zhao T, Liu H, et al. Do Male University Students Know Enough About Human Papillomavirus (HPV) to Make Informed Decisions About Vaccination? Medical Science Monitor : International Medical Journal of Experimental and Clinical Research 2020;26:e924840-1. https://doi.org/10.12659/MSM.924840

13. Zou H, Wang W, Ma Y, Wang Y, Zhao F, Wang S, et al. How university students view human papillomavirus (HPV) vaccination: A cross-sectional study in Jinan, China. Human Vaccines \& Immunotherapeutics 2016;12:39.

https://doi.org/10.1080/21645515.2015.1072667

14. Smolarczyk K, Pieta W, Majewski S. Assessment of the State of Knowledge about HPV Infection and HPV Vaccination among Polish Resident Doctors. International Journal of Environmental Research and Public Health 2021;18:1-18. https://doi.org/10.3390/ijerph18020551

15. López N, Garcés-Sánchez M, Panizo MB, de la Cueva IS, Artés MT, Ramos B, et al. HPV knowledge and vaccine acceptance among European adolescents and their parents: a systematic literature review. Public Health Reviews 2020 41:1 2020;41:1-24.

https://doi.org/10.1186/s40985-020-00130-9

16. Trucchi C, Amicizia D, Tafuri S, Sticchi L, Durando P, Costantino C, et al. Assessment of Knowledge, Attitudes, and Propensity towards HPV Vaccine of Young Adult Students in 
Italy. Vaccines 2020;8.

https://doi.org/10.3390/vaccines 8010074

17. Baldovin T, Bertoncello C, Cocchio S, (CA), Fonzo M, Gazzani $\mathrm{D}$, et al. Perception and knowledge of HPV-related and vaccinerelated conditions among a large cohort of university students in Italy. Human Vaccines \& Immunotherapeutics 2019;15:1641. https://doi.org/10.1080/21645515.2018.1564432

18. Zou H, Wang W, Ma Y, Wang Y, Zhao F, Wang S, et al. How university students view human papillomavirus (HPV) vaccination: A cross-sectional study in Jinan, China. Human Vaccines Immunotherapeutics 2016;12:39.

https://doi.org/10.1080/21645515.2015.1072667

\section{STUDENT'S KNOWLEDGE AND OPINION ABOUT HUMAN PAPILLOMA VIRUS AND ITS VACCINE}

D. Banaitytė, E. Jauraitė, S. Kaselienè

Keywords: Human Papillomavirus, opinion, knowledge, students, vaccine, attitude towards vaccine.

Summary

Each year, 450 new cases of cervical cancer are registered in Lithuania. Scientific research proved that human papillomavirus (HPV) has an important role in pathogenesis of cervical cancer, so sickness rate can be decreased by using vaccines from HPV. Medical staff play a major role when it comes to the education of the general public and can determine faster vaccination rates. However, there are only a few studies made to evaluate future medicine specialist opinion and knowledge about HPV and its vaccine.

The aim - to evaluate the knowledge and opinion about $\mathrm{Hu}-$ man Papilloma Virus (HPV) and it's vaccine amongst Medicine and Nursing students of Lithuanian university of Health sciences

Methods - 278 students of Faculty of Medicine and 58 students of Faculty of Nursing of Lithuanian university of Health sciences were interviewed using an anonymous questionnaire. Interviews were carried out from February 2020 to February 2021.Statistical analysis was performed using IBM SPSS 26.0. Chi square test and $\mathrm{Z}$ test were used to determine the differences between the groups. Statistical significance was set as $\mathrm{P}<0.05$.

Results - Medicine and Nursing students knew how the virus spreads: $94.3 \%$ chose sexual transmission, $21.8 \%$ - vertical, $35.7 \%$ - close contact. $93.2 \%$ of students know that HPV causes cervical cancer, however only $35.1 \%$ knew about penile cancer and $23.3 \%$ chose warts as an option. $86.6 \%$ of the respondents have heard about HPV vaccine. More than half $(54.2 \%)$ of the respondents agreed that both men and women can be vaccinated from $\mathrm{HPV}$, and $58.2 \%$ knew that it is recommended to vaccinate before first sexual contact. More than $70 \%$ of the students agreed that they lack knowledge about HPV and its vaccine and would like to know more. Only $11.6 \%$ of the respondents are vaccinated from HPV. $23.8 \%$ unvaccinated men and $45.1 \%$ women are planning to do so in the future. $78 \%$ of the respondents who will vaccinate their children, men, and upperclassmen (4-6th year) are more willing to do so $(\mathrm{P}=0.05)$. Year 4-6th students had better knowledge and were more in favour of the HPV vaccine $(\mathrm{P}=0.05)$.

Conclusions - Even though Medicine and Nursing students know the basic information about HPV and HPV vaccine, their knowledge is still lacking, and the majority of respondents would like to get more information about it.

Correspondence to: banaitytedovile97@gmail.com

Gauta 2021-09-07

\section{KVIEČIAME PRENUMERUOTI „SVEIKATOS MOKSLŲ“ ŽURNALĄ 2022 METAIS!}

Žurnalas „Sveikatos mokslai“ (Index Copernicus, EBSCO host (Academic Search Complete), Gale (Academic OneFile), ProQuest (Ulrich's, Summon), Australia (ERA) 2012 Journal List (ERA ID 34962) skirtas visų specialybiu gydytojams, slaugytojams ir kitiems specialistams, spausdina mokslinius straipsnius lietuvių, anglų kalbomis. Reikalavimai straipsniams atitinka mokslo leidiniams keliamus reikalavimus. Žurnalas spaudos kioskuose neparduodamas. Žurnalą, kuris leidžiamas kartą per du mėnesius, galima užsiprenumeruoti visuose Lietuvos pašto skyriuose ir internetu: www.prenumeruok.lt

Prenumeratos kaina nesikeičia: visiems metams - 36 EUR, šešiems mėnesiams - 18 EUR, keturiems mėnesiams - 12 EUR, dviem mẻnesiams - 6 EUR. Prenumeratos kodas: 5348.

Žurnalo autoriams straipsnių spausdinimas ir jų internetinè sklaida mokama.

Redakcija 